\title{
Causes and Impact of Migration : A Sociological Study of Emigration From Kandebash, Baglung, Nepal
}

\section{Introduction}

Tika Ram Gautam•

People are moving from one place to another since ancient period, which is a continuous international phenomenon resulted due to complex mechanism, involving social, economic, psychological, political, institutional and other determinants (Singh, 1998). Migration is a form of geographical or spatial mobility, which involves a change of usual residence of a person between clearly defined geographical units. A person who crosses the boundary of own country or places of country is called an out-migrant. Emigration refers to movement out of a particular territory in connection with the international migration (Bhende and Karnitkar, 1998). On the basis of assumed causes influencing human movement, international migration can be broadly categorized into two groups: voluntary and involuntary (Peterson, 1978). This article concentrates on voluntary international migration in Nepal although in many cases, the difference between voluntary and involuntary movements may be unclear (David, 1970: 73-95).

The current situation of population in Nepal results in part from both emigration and immigration. Historically, three forms of emigration are evident: a) movement related to military recruitment, b) Movement for agricultural and other economic activities, and c) marriage migration. More than 90 percent of all emigrants are from Hills and Mountains of Nepal (Subedi, 1991).

In past, Nepal had been a country of destination for immigrants from both north and south. Instances of emigration from Nepal were not known then. However, after the Treaty of Sugauli (1816), Nepalese people started to migrate to India to be recruited in the British Indian Army. The raising of the first Army Battalian (Sirmour Battalian) from among the Nepalese prisoners of war was the major turning point in the large-scale emigration of Nepalese people (Kanskar, 1984). Of course, there were Nepalese from Kathmandu who used to go to Tibet for business but their numbers were limited (400 to 500 families). Therefore, it was not of a large-scale nature and played very insignificant role in Nepalese emigration phenomenon. Besides, the recruitment in British-Indian Army, new agricultural programmes, carried out by then British India in the provinces such as Assam, Darjelling, Burma attracted many peasants of Nepalese Hills to work and settle there. Later, many people also started and still continues going India to work as Watchmen (guards), hotel boys etc. and the recent trend is also going on to European, American and Arab (UAE-United Arab Emirates) countries for skilled and unskilled jobs (Singh, 1998). The history of emigration in Kandebash Village Development Committee (VDC), Baglung was started from 1914 A.D. (Gautam, 1999).

There are no empirical records on emigration till 1951. The 1952/54 census of Nepal was the first to report the volume of emigration from Nepal. According to this census altogether 1,98, 120 Nepalese were absent from home for more than six months prior to census taking. Subsequently, all successive censuses (except 1971) provided the figures of absentee population from Nepal. The figures of absentee population from Nepal and information on absentee population in the censuses were collected from the household schedules.

Migration is one of the most important trend and process in Nepal. Several studies have been conducted in this field by different research institutions and scholars. But most of these are

\footnotetext{
- Head of the Department, Sociology/Anthropology, MMC, Baglung.
} 
concerned with internal Hill to Terai and rural to urban types of migration. Subedi (1991) has also studied about emigration in Nepal. These studies have provided only the trends of emigration and causes as "Push and Pull" factors. Actually, these studies don't portray the causes and impact of emigration in the point of origin in detail from sociological perspective.

Emigration is considered as a response of the people to the existing socio-economic and political conditions of a country. Many people who are unable to fulfill their needs with the environment around them and find it convenient to emigrate rather than fight for a change. It is observed that generally most unemployed young males have a tendency to emigrate and thus even as short-term emigration may relieve the unemployment problem to some extent. I would like to argue that emigration brings problems in the long run causing a shortage of necessary manpower for developmental activities of the nation, including negative socio-economic impacts.

The increasing trend of emigration has created a serious problem in using resources and its implementation in development plans and policies. Kandebash VDC and most of other parts of Baglung district are affected by intensive emigration. This article tries to explain causes (push and pull factors) including socio-economic and demographic impact of emigration at the local level. I argue that the trend of emigration including causes and impact has been changed since 1990s. In the beginning, poor and food deficit family members followed emigration to support their livelihood. But now emigration has been common practice to rich and food sufficiency family members.

The number of out migrants is higher while there is no record of immigration into this VDC. This has resulted in shortage of people of working age i.e. active male population. According to the local people, most of the people were employed or engaged in their own agricultural work before 1950. They further add population growth increased, the rate of unemployment, which is the main cause of emigration. The local people were forced to search employment. India was the best alternative for them. The number of people who are out of this VDC and have gone to other foreign countries is $28.2 \%$ (Gautam, 1999). This shows how is difficult it is to lead life in this VDC, and equally highlights that this is not a lasting solution to the problem.

The majority of out migrants go to India. Since, out migrants dominate the migration stream, this has been the main focus of this study. Some of the impacts of out migration are having emerged: like shortage of skilled manpower; absent of male members, change in demographic structures etc. Findings of such impacts could be significant in other part of the country as well. Therefore, I have intended to deal with the problem of emigration to a larger extent. I would like to argue in this article that local level production is decreased and dependence on market goods is increasing due to remittance from the emigrants. The social relationship among family members and neighbors is weakening day by day. Emigration has been the common phenomenon to both rich and poor families. Poor are emigrating for their livelihood while the rich are for prosperous economic conditions. The investment in the emigration differs according to economic class. Poor are immigrating to India and Arabian countries because small amount of sum is enough and rich are immigrating to European and American countries like Japan, German, England, America, Canada, Australia etc.

\section{Location}

Kandebash VDC lies in the southwestern part of Baglung district of Dhaulagiri zone of western Nepal. It has total area of approximately $15.02 \mathrm{Sq}$. Km, which is equally extended north-south and east-west and looks like a square and at an altitude of 900 to $2200 \mathrm{~m}$. above the sea level. On the basis of climate and geographical setting, this VDC can be divided into two broad zone i.e. the upper part (Lekh or temperate) and the lower part (Beshi or sub-tropical). Lekh is 
characterized by cold, frost, snowfall and fog in the winter and heavy rainfall and cool wind during summer while the Beshi is characterized by cold in the winter and heavy rainfall and hot during the summer.

This VDC is bordered by Hatiya VDC in the east, Arlangkot, a VDC of Gulmi district, in the west, Sukhaura VDC in the south and Malma VDC, in the north. There are altogether 441 households in the VDC and the total population is 2710 with an average household size of 6.1 (DDC, Baglung, 1998).

The VDC is rich in natural resources like forest, water, wild animals, slate stones, minerals (iron) etc. Villagers through the ages have exploited the forest and pastureland in Lekh and water in the Beshi. The forest has provided the villagers fodder, fuel wood, timber, nettle fiber and wild green vegetables. In the past, the villagers were diligent miners of Iron. But this is no longer in practice today. However, these days, quarrying of stone and slate is a very common practice in the village.

Subsistence agriculture with animal husbandry is the main source of livelihood of the village people and it is now largely supplemented by foreign services. Ecologically and climatically the Lekh is not suitable for agricultural production. Arable land, with its quality, in the Lekh is mainly the Sim,Char and Panch (third, foruth and fifth class), which are less productive, and require more manure. Arable land in the Beshi includes mainly Awal, Doyam and Sim (first, second and third class), which are more fertile for agricultural production. Most of the arable lands are Pakhobari (dry land) and a few Khet (irrigated land). The third type of land is called Kharbari (grass land) for cutting fodder for animals.

The caste and ethnic groups of Kandebash can be classified into three major group such as Brahmins and Chhetris (58\%), Tibeto-Burmese group-Magars, Gurungs and Thakalis (26\%) and the remaining Dalits (Damais and Kamis) (Gautam, 1999). Almost all the people, in Kandebash VDC, various ethnic groups, mostly practice Hindu religion, including Buddhist community such as Gurung, Thakali.

If we see the whole population of Kandebash VDC dividing into the three broad age groups young, adult and old, young group is $48.8 \%$, the adult age group (15-59) is $46.4 \%$ and only $4.8 \%$ is in the age group 60 and above. Being an area of origin of emigration middle age group (15-59) population is found less in number. This happens because economically active young and unmarried male are outside from the area (Gautam, 1999). At the present, young females of emigrated people are moving to urban centre to educate their children. The old couple is now left at home who are unable to produce the things they need from their farm. The young couples are trying to live outside the village either buying house and land or in rent in the cities. It has cause an adverse effect in the village population.

\section{Economy}

Agriculture is the major basis of village economy which is now replacing with remittance from the emigrants. Most of the fertile lands are also now left uncultivated or just formal cultivation. Beshi includes irrigated land (Khet) while the Lekh has unirrigated land (Bari) and grass land (Kharbari) in the VDC. $43.5 \%$ people have no irrigated land, 12\% have not dry land (Bari). Majority of the households have small size (less than 10 ropani $^{1}$ ) of landholding which is not enough one family in the local area. Some Dalits are landless (Gautam, 1999). In past, some

\footnotetext{
${ }^{1} 1$ Ropani $=5625.89 \mathrm{ft}=0.0052$ hectare
} 
households who have large-scale land were known as prosperous family but now economically prosperous family buy market goods because they left to produce local cash crops like ginger, chilly, onion and food grains. Even the poor families have left to produce both cash and food crops.

Majority of the households (38.8\%) have kept buffaloes and cows between the size 3-4 and $23.8 \%$ have the size $3-4,23.8 \%$ households have less than $3.19 .5 \%$ households having the livestock size of 5-6 and 7+ respectively follow it. During interview it is reported that the size of the livestock has decreased due emigration of active males to India and some members are engaged in study. On the other hand, females with old and child members are staying at home who are unable to keep cattle in large number. Some Brahmins are now keeping poultry though religiously it is restricted in the past. Keeping a goat is now common in the village because it is the source of cash income.

$32.8 \%$ households have $1-10$ muri $^{2}, 28.5 \%$ have the size of $11-20$ muri. It is followed by $26.8 \%$ growing 21-30 muri in a year. Remaining households have product of 31 muri and above. But today people have left cultivation. They are not keeping enough cattle which reduced the quantity of manure (compost) necessary for agricultural production. Agricultural production is decreased. But people are not worried because they bought food from the market easily. Most of the families have to face food deficit condition. This can be faced when some amount of money can be invested in purchasing foods. For this, cash is needed and people migrate to other places leaving their own village.

\section{Case Study I}

One Brahmin immigrated to India 30 years ago. He left home because of large family (11). He returned from India and got separated from his joint family. He had only one house and 0.5 ropani of dry land (Bari). He left his wife at home and went back to India again. His wife said that she lived eating fruit like Amilo or Sour (Citrus aurantium) and buds of flower of Kapro (Ficus lacore) and other things. Later her husband started to send money and with that money, they bought and added a little piece of land. Husband lived in India earned large amount of money. He used to come and add pieces of land every time and for his son and daughter's education. His wife says that they have 14 ropani irrigated land in the village at present. Also adds that it is now enough for living but useless to stay at home idly.

People in the VDC are unable in cash income generating process, but they have to purchase things of daily needs with cash from shop. The villagers who have no source of cash income fall in debt. $55.4 \%$ of the total households are in debt. Out of this $28.5 \%$ are from Brahmins/Chhetris caste group, $16.6 \%$ Tibeto-Burmese group and 10.3\% Dalits(Gautam, 1999). In the field study it was found that a man (from non emigrated household) who had bought a buffalo in the month of Bhadra had promised to pay the sum of Rs 8,000 in Maghesakranti, but he was unable to pay and was ready to pay the interest of the rate 2 percent per month. This proves that there is neither any source of cash income nor live without debt. But emigration has improved their economic status in the village.

\footnotetext{
${ }^{2} 1$ Muri= 20 pathi, 1 Pathi $=8$ mana, 1 mana $=10$ muthi, about 27 pathi=1 quintle.
} 
The VDC is far from district headquarter and has no access to motor able road. It is very difficult to carry roofing Zinc plate-Tin (Sheet of corrugated iron for roofing) in the VDC. Most of the houses have thatched roof, which was built before 10 years. But for the last ten years people are quarrying roofing stone slate in their own villages at the upper (but middle) part of the VDC. Most of the houses are roofed with stone slate today. Some of the people with good income have built multi-storied house. Poor have only the thatched roofed houses.

Total absentee population percent and absentee population of Dalits is quite low. It means that the emigration from Kandebash VDC is dominant pattern of Brahmins/Chhetris due to their difficulties in earning cash. Brahmins and Chhetris do not like to involve in low level of work because of their so called prosperous status in society. Lack of food compels people to move towards food secure area or the source for cash (income) is available. The number of emigrants from food deficit was greater than the number of emigrants from food surplus family. But today it is just opposite. This is also true with many other studies (mentioned in review) of far western region of Nepal. The emigrants from food sufficient and surplus reported that it is due to the lack of cash income. Unmarried are more migratory than married because they are supposed to be independent. But this is only in case of voluntary migration. The case is just reversed in this case. Married emigrants are more here because they are compelled to look after their family.

The larger size of the family has greater chances of emigration. Most of the emigrants from this VDC are literate and educated. The first arrivals of emigrants at their point of destination are completely new experiences for them. It is the contrast for them both physical environment and human relation. Surprisingly these people don't have to face the problem of finding a place for housing. Those people before migrating are careful enough to take all the precautions and their arrivals in India are carefully planned. It is said in the group discussion that generally some relatives or friends who have already been working in India accompany them. Moreover finding a job also is not extremely difficult. They don't face the problem of frictional unemployment because of low types of job. Friends and relatives usually look into possibilities of getting a job. So a villager, who is not clever in the sense that he is unable to cope up with the environment in the beginning, is cautious enough not to move without some employment guarantee. Money is obtained from relatives, friends and other who wishers to meet the expenses during the unemployed period.

Nepalese emigrants are known by the name of "Bahadur" or 'Gurkhas' in India. Our predecessors have shown their bravery and honesty. So they were known as loyal and fierce fighters. Therefore, they have an easy and early access to employment. But nowadays, due to increased numbers of emigrants and their dishonesty, it has become difficult for better opportunities. Although the Indian government has taken some steps to restrict or regulate the access of emigrants to the labour markets and consequently the office does not provide employment to these emigrants, but Gurkhas are still preferred by Indians in their private homes, factories, cinema halls and some corporations, but to find employment as Watchmen (guards) or household servants. Those who find employment in factories are run by foreign collaboration. Surprisingly it is known that they were also employed in the armed forces. Such types of jobs are never advertised publicly (See Gautam, 1999 for details).

\section{Causes of Emigration}

From interview, people from Kandebash VDC seem to immigrate to India for various reasons. They are categorized under "Push" and "Pull" model.

\subsection{Push Factors}


The information obtained from emigrants, indicate that push factors are quite responsible for emigration from this VDC. Push factors exert pressure on them to leave the VDC in search of opportunities. The Push factors of the villages are explained below.

Agriculture was identified as one important employment sector of the VDC. Yet, $71.8 \%$ of the total respondents reported that they could not find other jobs in the village. They were virtually forced to move out of their village to find a job for various expenditures like daily goods, education, health etc. Increasing population also has exerted pressure on the limited resources and compels to look for other alternative income source. This means that the lack of jobs in the village is one of the main reasons for emigration (Gautam, 1999). But today people with small local jobs like teaching, small shop etc. are also emigrated for high income jobs. Similarly, young literate males do not give interest to be engaged in the agricultural activities and seek for the alternatives which cause unemployment in the village.

There are different things of consumption to fulfill daily needs. There is no easy source of income. People must afford education and health facilities. Now a day, emigrants emphasized on education and health services of their families. It is clear from the fact that some emigrants' families are in the cities to educate their children at Boarding schools. People who do not have cash borrow from moneylenders. Due to the lack of cash/income or of employment opportunity, this debt increased continuously. After few years, people are unable to stay at home due to these bad economic conditions of indebtedness. Therefore, they again look for the way of emigration.

Bishnu, a Brahmin had taken NRs. 2000 rupees loan in 1975 from a moneylender. He was unable to pay back for some years. The loan doubled in every three years as per local interest rates and reached to a sum of Rs. 25,000. He was unable to pay that loan. He sold his land and shifted to another place of the same village.

Increased population and consumption of services increase expenditure. Large numbers of family members need large quantity of food, clothes and other things. In the study area, expenditure has increased in education, health and purchasing things of daily needs together with food. Some other causes, like modernization, broad relationship etc. have also increased the expenditure. To fulfill these requirements increased amount of cash is needed. Sources of cash income in the village are very limited. People emigrate to have cash.

Some young males are leaving village due to the present conflict because they are afraid of being enforced to join or become victim of armed Maoists or Royal army. They think that going either India or other countries is safer.

\subsection{Pull Factors}

The pull factors that attract the emigrants are also responsible for emigration of people. The majority of the people have chosen India as their destination as well as some other foreign countries. As we have seen that among 19.8\% only 1.6\% countries other than India. Nowadays, the number of people going to foreign countries is increasing.

The trend of emigration to India supports the Ravenstein's law (Gautam, 1999) which states that migrants try to minimize distance. The trend of migration in Kandebash VDC also supports his second part of law which says that migrants proceeding long distances generally go by preference to one of the great centers of commerce and industry. Though here is no information what so ever, for emigration to other sectors of India and other countries but the percentage of Indian emigrants among total absentee is $97.4 \%$. The reasons for selecting India as a destination for migration are explained below. 
$31.3 \%$ of the total respondents accounted for easy availability of unskilled work (watch man, domestic servant, cook, driver, sales man etc) as their main reasons for choosing India. They also mentioned that whether they are skilled or not, any kind of work was easily available for them. But today people are searching various opportunities to emigrate. They often take different trainings to develop skill for easy emigration.

This factor has dual role in attracting emigrants to India. On the one hand people living in India provide necessary information to their family members, relatives and friends. On the other hand they provide a kind of linkage in obtaining shelter, food and other necessary things during unemployed periods in India. 25\% respondents reported this factor as the main reason for selecting India for emigration.

The third important factor is that it is very easy to enter in to India. It is a bit difficult to go to some places of India such as east Assam, but easier to go to middle and west part of India like Delhi, Bombay, and Calcutta etc. The simple checking system at border and no provision of passport and visa make entry and exit very easy. Furthermore easy transportation service also helps to make entry easy. In this study $21.8 \%$ emigrants identified it as their main reason for selecting India. But today people are looking for other countries for better income. Most of the emigrants are now in other countries rather than India.

Some of the respondents reported that they had moved to India to join in the Indian and British army. 6.3\% people in the VDC are recruited as Indian and British Army. This trend of recruitment is decreased because there are other ways of going foreign countries for better income.

Moreover emigration, to India and other countries, is now considered a tradition among villagers. In this context the main reasons for concentration of emigrants in some particular city or area is fairly simple. As some men of village obtain employment in a particular locality and 'get established' (easily live), other men tend to go to same place to live in locality where they have relatives and friends. Men quitting a job and returning home usually send a member of their own family or close relatives as a replacement. Once established, the bond to a particular city or town in India continues and grows firmer. $90 \%$ of the men in India from Jyamire and $85 \%$ of those from Chalisetola were in Delhi in 1990. But today nearly 50\% are in Arabian and $10 \%$ are in European and American countries.

Social facilities of towns can be taken as important incentive for migration. But in this case, most emigrants are "economic failure" in their place of origin. That is why they are compelled to search for jobs in a foreign land. Very few respondents reported that they went to India to increase their educational status or to increase social status or to understand India closely. It can be concluded that the majority of emigrants didn't emigrate to increase educational or social status or to enjoy urban facilities. But they emigrated because of ' economic failure' at homes and their objective was to raise money in order to upgrade their economic status. It is true in the sense that some people have got opportunities to go to USA, Japan, Germany, United Kingdom etc. as a cook, student, businessmen etc visas.

\section{Impact of Emigration}

When people move from place to place they make adjustments in their personal and sociocultural lives. It is difficult to ascertain the true social or economic benefits of their mobility. Many factors affect calculation/analysis of benefits and costs involved when people move from one place to another place. Firstly, we cannot say that movements are always beneficial. Secondly, the advantages and disadvantages of moving along are not symmetrical. Because of all 
these things the study is less able to analyze the true 'social and economic benefits' of the emigrants. Whether the emigration has demographic effects? How emigration is affecting social values? Whether emigration has favorable or unfavorable effect in the village life? Whether emigration has economic advantages or not? This section is concentrated on certain demographic, economic and social variables. Though it attempts to analyze the above variables in some details, there have been some limitations on the analysis because of lack of accurate information.

\subsection{Demographic Impact}

Emigration has various demographic impacts at village level of Kandebash VDC. It changes sex ratio and the dependency of labour force. Young people of age group (0-14) are 38.2\% of total population. Similarly $58.1 \%$ population is of active age group (15-59). The old age group (60 and above) has 3.1 percent. As explained before most of the emigrants are young males of age (1559). Emigration reduces masculinity ratio of population. Obviously the absence of young males from the village increases the proportion of other group women, children and old. But today young females are moving urban centre leaving old couples in the village.

On the other hand the data shows the reduced numbers of active population in the VDC creates lack of labor force. This lack of economically active population restricts the progress of development and other works. It was noticed that there was $70 \%$ female participation in an irrigation cannel construction work.

It is also noticed that the number of child or young age group is less than other group. This may be either due to decreasing birth rate or increasing death rate or may be because of combination of both factors. However, it is difficult to find out exactness of both factors because of lack of statistics. But on the basis of field observation of research area, it can be said that India emigration has not reduced birth rate. This is because the average stay of emigrants in India is approximately one year. They seem to come on leave frequently and do not break ties with their families. It means that emigration has not controlled the husband wife relation for producing babies in time. Moreover some emigrants take their wives with them to India and other countries. If they do not do so, they permit to live in the urban centres.

\subsection{Economic Impact}

Emigration of people from Kandebash VDC is certainly having positive effect on the economy of the VDC. Though the VDC has economic deficiency, cultivation is not neglected. Upper part (Lekh) of the VDC has no irrigation facility. Finding employment in India, nowadays males are neglecting agriculture. But immigrating to India for employment is not a permanent solution. These people have to come back, to find their lands poor in fertility and management. Let us see some detail of economic variables.

Emigration affects supply of labour force. Majority of the economically active male population seems to be outside the village. The study (Gautam, 1999) shows that $52.2 \%$ of total active male population is found as emigrants at the end of 1998. Consequently, it is found to have some effects on the construction and manual activities in the VDC. And it is found that the majority of emigrants are young males of upper and lower caste. Therefore, even if there is a large potential labour force with females it is not possible for many manual works to be done in the VDC. 
Experience shows that one NGO, Baglung Community Development Project (BCDP), could not conduct drinking water project in Jyamire Village of Kandebash VDC due to lack of labour force. Some times the emigrants take their wives with them create more shortage of labour force during the construction of school and road. These cases show that shortage of labour force. On the other hand I argue that most emigrants went to India because they were unemployed. Unemployment is still the strong force, which urges villagers to leave their home. The above case i.e. finding employment in the village is seasonal, part time and uncertain. Nevertheless above two points are not contradictory. In such a circumstance, most of active population is out of the village. So how can developmental activities and mass participation be possible? Those who have returned from India and other foreign countries economically better off than their counterparts and think it is not better to work in Nepal as laborers.

Agricultural productivity has decreased in the village because of reduced quantity of manure. Due to the lack of labour force i.e. active male, the size of livestock is very small in the village. Most of the respondents reported that they had reduced size of the livestock after their family member's immigration to India and other countries. In this context emigration has negative impact in pastoral activities.

Hill agriculture is in a bad state because of loss of fertility of land; rain, erosion and landslides. Emigration is also responsible to some extent. People are not interested in cultivating their limited and less fertile land because they can find an alternative and easy way of finding employment in India and other countries. No activities are made to increase the fertility of the soil. The impact of male emigration on agriculture is those females normally carry all the agricultural activities improve agriculture and attempt to increase total production. But females are intended to live in cities leaving their old couple at home. During the study, one respondent reported that he had better crops (wheat and maize) because his son stayed at home and looked after the farm very well. So, emigration has no adverse effect to the farm of those, who have large labor force and only a few members going to India and other countries. But emigrants left to cultivate their land for larger production. Emigrants, with larger income, have either bought land in the terai or build house in the cities. This phenomenon ultimately empties the cash from the village.

Taking away some labor force from this agricultural sector will not decrease production. But the question is how far the female population acts as a substitute for male population? Is India emigration a permanent solution to the economic problems? Do the people who earn money invest in their village wisely? These are the questions, which are difficult to answer. Though production is reduced to some extent due to shortage of labour force, food sufficiency situation may emerge after emigration. This is because; some food is saved due to the absence of their member (s) of the family. They may also fulfill the need of food supply using the remittance send by the emigrants.

We cannot see much occupational change in emigrants and non-emigrants. Heavy dependence on agriculture still prevails in the post emigration period. Only a small scale of occupational shift has taken place in ploughing by upper caste Brahmins due to the lack of labour force (specially lack of lower caste people as well as Chhetris) to plough land.

Since employment in India and other countries is now considered as the first best alternative than agriculture, emigration is considered as an important source of income. Myron (1973) thinks that apart from providing economic and political safety valve for the surplus population of the Hill areas of Nepal, emigration has been significant source of income for Nepal. The British government alone pays one million pounds sterling a year in pensions to more than twenty 
thousand retired "Gurkhas" and Indian government reportedly provides several times that amount over a hundred thousand retired soldiers.

Though this may seem to be the state of affairs, still then, recruitment in both Indian and British army is declining. From Kandebash VDC only about $10 \%$ reported as serving in the Indian and British armies. Macfarlane (1976) finds that emigrants as a whole usually brought back about a quarter of their income not of the cost of the food and accommodation and contracts with soldier emigrants from the Limbu villages in Eastern Nepal studied by Caplan (mentioned in Macfarlane, 1976) who were bringing back about 60 percent of their income. It is estimated that the emigrants (about 200) from Kandebash VDC earn Rs. 5, 75,000 IC and they save Rs. 3, 00,000 IC monthly in India (Gautam, 1999). It means they bring 52.1 percent of their total income either in cash or in kinds or in both forms in their village from India alone. However, transportation cost is not excluded from this figure.

In the field study (Gautam, 1999) it is said that major portion of the income is spent on consumption. They use their India income in buying food grains, clothes, paying taxes and maintaining other household expenses (feasts, festivals etc.) including wedding ceremony (to give money to bride and bridegroom). Moreover some portion of their income is spent on luxuries and capital consumption like watching TV, playing Cashette player, drinking, picnic, festival ceremonies etc. Very few emigrants use their earning in buying a new plot of land or building a new house. In this case only $20 \%$ emigrant's households have bought pieces of land. Thus on the one hand agricultural land is neglected. Food is consumed from the market and the income is spent on those consumption materials which ultimately creates dependency. In the lack of remittance, the village economy will be worsened in the future.

Since most of the earning is spent on consumption, it has no contribution in capitalization of the economy. No visible improvement can be seen in the village as a consequence of emigration.

\subsection{Social Impact}

Emigration in Kandebash VDC has both positive and negative social impact. The major issues are discussed here.

The study (Gautam, 1999) concludes that the literacy and educational status is improving. Some of the emigrants (5\%) have improved themselves while in India and other countries. Emigrants seem to change the beliefs of people. This is evident from an interview and observation, as only a few respondents have faith in Shamanism.

The social status of the village people has changed. Low caste and lower class people reported that they have now good treatment from the higher caste and class people. It is because they have cash money and are able to purchase small piece of fertile and grass land. Politically, emigrated people seem to be more aware. They have taken some political position like ward representatives in the VDC as they mention they had no knowledge about leadership before emigration.

The desire to participate in festival was not effected by emigration. It was found that respondents desire to participate in religious ceremonies has not changed at all. Only a few respondents reported of having greater tendency. About half of the respondents reported of having interests in religious ceremonies. Recently, they have built two temples in the village. This shows that most of them are interested in religious ceremonies.

Though there have been some improvements, yet negative aspects have also arose. Respondents are greatly influenced by "demonstration effects" and 'ratchets' effects. A medical record (after 
discussion with the medical doctor at a medical shop) provided 10 cases of venereal diseases in one year. He said the emigrants picked them in India; pass it to their wives and girl friends in their village and the wives and girl friends pass down to others in the village.

Another common scenario is that many people have learned the habit of drinking alcohol and gambling. Home returned migrants are habituated to drinking alcohol and gambling. The respondents answered that they learnt it when they used was leisure time in foreign countries. Most of them performed heavy work so drinking was used as a source of relaxation. These people become an example to the villagers, and these practices have heavy economic and social consequences on their families and relatives. Emigration brings some family problems, too as some family heads and members do not return to their villages for some time or forever. The absence of emigrants for a long time creates social psychological anxiety. This case is stronger when the family head represents a strong factor for family unification. Emigrants found their wives tired and impatient in the husband's long and continuous absence. Some times wife elopes with other man. Five such jari cases were recorded in the village in the year 2005 AD.

Relationship among family members and neighbours has been changing in the village. Most of the young males and females are leaving their villages for urban centre. They are living permanently buying house and land or in rent. The old couples are alone at home. No one is there at home to look after them. Family members having cash income and no cash income have no good relationship at the present.

\section{Case Study 2}

One-man say Mr. Gautam of Kandebash-6, had left his home at the age of 12 years in the 1960. He went to east Assam called Tinsukia. He returned back to his home and got married with a woman. After his marriage he again moved there and lived for 4 years and came back to his home. He continued coming and going. It is said that he had been keeping cows there and selling milk. He had also taken some cash and had also added some land. By that time he got one son and two daughters. He again went to Assam to bring some cash to pay the loan to his land lenders. But this time it was revealed he had a second marriage in Assam. Now he has forgotten his original home. It is said that once he had returned to his family member. His first wife and children quarrelled with his former son and others. He again left his home leaving all his first family with his old mother. Since then he has not returned. His mother has died. But now it was not known where he was.

\section{Conclusion}

People from Kandebash VDC have emigrated because of certain causes (push-pull factors). The major reasons for emigration can be attributed to the following factors; unemployment, food deficiency, increased expenditure and interest of being economically prosperous. The other reasons included family causes (population pressure and conflict). These factors initiate the desire to go to other places specially India and other countries. At present, conflict has been one of the major reasons of emigration in the VDC.

The pull factors are associated with push factors. The economic factors associated with pull factors i.e.; easy availability of work (unskilled employment), cash payment and other benefits. The social factors are "bright light" of the city", adventure gossip of returned people from India and other countries and from friends and relatives staying in India and other countries. The 
physical things consumed by the emigrants and various activities including migration to cities attracted each people for emigration to other countries. It has been common to all class, caste and even gender cases. Attitudinal test show that the willingness to participate after returning from foreign countries was increased only by $12.5 \%$. Moreover, field statistics show that interest on business activities has been increased. But whether migrant's saving has a role in capital formation and development of rural economy will depend on the flow of remittances and their effects on the consumption and investment patterns of the family members remaining at home.

The above analysis shows that the life of the people tend to be better economically after emigration only on the basis of food sufficiency, social status, habits and consumption patterns. But this is a phenomenon, which is not going to continue for a long time. The high income generated is because of the convertibility of foreign currency. It might not be surprising that there might be an end of providing employment possibilities to the Nepalese citizens in the foreign countries in future, put many livelihoods at risk.

\section{Bibliography}

Acharya, H.P., 1978, Emigration in Nepal: A Case Study in Swargadwari Khal Village Panchayat, Kathmandu: a dissertation submitted to Tribhuvan University.

Bhende, A. and Karmitkar, T. 1998, Principles of Population Studies, Reprint New Delhi: Himalaya Publishing House

Bista, K.B., 1975, Migration in Nepal: A Study of Far Western Development Region, Kathmandu: Centre for Economic Development and Administration (CEDA).

David, H.P. 1970: In Voluntary Interational Migration: Adaptation of Retugeers in Bordy (ed), Behaviour is new environment, Adoptation of Magrants Populations. Bevetly Hills, Californica Sage Publication

Gautam, T.R., 1999, Labour Migration to India: A Case of Kandebash VDC, Baglung, A dissertation Submitted to Sociology/Anthropology, T.U., Kirtipur.

Gurung, S.B., 1973, Causes and impact of migration: Preliminary survey in Surkhet region, Kathmandu, Centre for Economic Development and Administration (CEDA).

Kanskar, B.V.S. 1984: Indo-Nepal Migration: Process and Prospects, Contribution to Nepales Study, CNAS

Khadka, R.B., 1979, Emigration in Nepal: A Micro level Study of Bayalpata Village Panchayat, A Dissertation Submitted to T.U.

Lee, E.S., 1966, A Theory of Migration in Demography, Vol.III , PP.47-57

Luintel, Y.R., 1997, Report from the West, Himal South Asia, Vol.10.PP.5.

Macfarlane, A., 1976, Resources and Population: A study of Gurungs of Nepal, Tribhuvan University, Kirtipur, Nepal.

Peterson, W. 1975: Spatial Distribution of Population in Dhading District. A Case Study of Population Distribution in Relation to Fullfillment of Basis Needs, Kathmandu, T.U.

Singh, M.L. 1998, Enigration from Nepal: Some Major Issues, Journal of Population Development, Vo, No. PP 37- 47

Subedi, B.P.,1991: Interational Migration in Nepal: Towards an Analytifal Framecrone, Contribution to Nepalese Studies, CNAS, Vol. 18, PP. 83 - 98.

Weiner, M., 1973, Political Demography of Nepal, Asian Survey, Vol.13 No.6 PP.617-30 